\title{
2.2 Spaces: Approaches and Perspectives OF INVESTIGATION
}

\section{Christian Wille and Markus Hesse}

Since the end of the 1980 s cultural studies and social sciences have been giving increased attention to the category of 'space'. The concomitant valorization of 'space' under the term 'spatial turn' has gone on to produce a series of differentiations of which the 'topographical turn' plays a role particularly in literary and media studies. The term 'spatial turn' follows up on discussions of post-modernity and was promoted in particular by the geographer Edward W. Soja. In using this term, he called for giving greater consideration to spatial categories and conditions of social development in general, but also understood these as a social contingency of space - not as a spatial constitution of society. Drawing on Henri Lefebvre (1991 [1974]), Soja (1989 and 1996) argues in favour of departing from space as a fact of natural space and instead directing the focus on its processes of social production. Practically around the same time Benno Werlen used the identical approach for developing an action-theoretical conception of geography as a social science that aimed to overcome the notion of geography as a science concerned exclusively with space (see Werlen 2008).

It is precisely this frame of reference in which the present volume investigates 'space' in its processes of social construction in various thematic contexts. What is relevant here is the socially emergent perspective on space broadly received via Lefevbre, in turn building on Simmel (1992 [1903]). Its unabated currency and continuous development commenced in the 1990s, triggered by a series of social and technological changes. These prompted an increasing number of questions in the social sciences and cultural studies that can be narrowed down to two seemingly opposing positions: the apparent disappearance of space and the apparent return of space. This refers first of all to the despatialization thesis which argues that space has lost a great deal of its significance with the development of transport and communication media, space-time convergencies and the borderless society. At the same time, the spatialization thesis proceeds - with the same arguments - on the assumption that there is a growing diversification of spatial contexts (see Kajetzke/Schroer 2010: 195). This already suggests that the apparent disappearance and a corresponding return of space are not consecutive but simultaneously observable processes that are furthermore dependent on interpretation. Also, both need not necessarily be seen as being contradictory, but can be conceived as closely linked dialectic categories. The relationship between despatialization and spatialization, which has to be defined empirically, constitutes one of the subjects in this volume that deals with phenomena in the context of borders and border regions. This is prompted by the consideration that it is particularly in the context of border negotiations that special demands are made on the theoretical category of 'space'; or in other words: here, processes of despatialization and spatialization 
can be observed particularly well on an empirical level. Bachmann-Medick (2006: 297) supports this observation when she points to "borders and border-crossings" as "salient research areas of the spatial turn." ${ }^{26}$ One of the recurring research questions in this volume therefore concerns itself with spatial constructions that emanate from practices of institutions, the media and everyday life and are linked to processes of the establishment, crossing and expansion of borders.

The spatial concepts called on to this purpose represent in each case different analytical approaches to 'space'. This diversity is reflected in the relevant literature also there where the disappearance of space is emphasized and reference is primarily made to geographical spaces and nation states. By contrast, studies that highlight the return of space tend to draw on - besides the physical-material or territorial space - a relational figure of space as expressed, for instance, in social, virtual or transnational spaces (see Schroer 2008: 135). These different types of space (that also circulate within the disciplines) already suggest that is impossible to find a universally valid definition of space and that a number of different spatial types are - and need to be - mustered simultaneously to investigate the productions of space. We will therefore proceed to first clarify some essential approaches to 'space' and subsequently present the research perspectives chosen in this volume.

\subsubsection{Approaches to 'Space'}

Regarding the subject of 'space', we can differentiate between various concepts and their theoretical preconceptions that each have had their own specific historical development in spatial discourse. To start with, one widely held view of classical geography is based on an understanding that posits space first as a material substance, attributing to it an influence on the objects contained therein and assuming an entity with a nature of its own. This understanding of space is rooted in the classical scientific school of thought in the tradition of Isaac Newton, which holds that space is the causally effective container for all natural, material as well as human processes and artefacts. This mechanistic classification of space has also come to be referred to with the metaphor of the container. Building on a series of causal-analytical fallacies, thinking in categories of container space also informed the first conceptions of human geography developed in the early 2oth century by Friedrich Ratzel and Alfred Hettner. Soon after, the logical connection made between terrestrial conditions and a specific disposition of society was to become, with fateful consequences, a key feature of the Nazi policy of conquest, which was also justified with the polemical term of Lebensraum (living space) drawn from biology and the notion of the alleged 'Volk ohne Raum' ('people without space'). Even today, such an essentialist, territorialized notion of space

26 | Personal translation of: "Grenzen und Grenzüberschreitungen” [als] “[...] herausgehobene[n] Forschungsfelder[n] des spatial turn."

E-Book von Christian Wille, christian.wille@uni.lu 27.01.2016 17:18

Copyright 2016, transcript Verlag, Bielefeld 
continues to be at the root of many concepts of spatial planning, even though the binding powers of the spatial have long become fluid and the circulation of people, commodities, capital, information, policies etc. have rendered spatially-oriented hierarchical patterns of order almost obsolete.

In addition, a relational perspective understands space secondly as structure or as an abstraction of dispositional structures of the physical-material objects that constitute it. This understanding of space still has its origins in the abstract conception of geography as a spatial science, which was promoted by Walter Christaller's central-place theory as well as the emerging quantitative methodology of regional sciences and geography (particularly in the USA). While the original assumption of geography as a causal science of the earth's surface remained in place, space now constituted itself as a "form of order of things in juxtaposition across varying distances" 27 (Werlen 2009: 150). Accordingly it is understood as a "constellation of conditions that are marked by a specifically arranged structure and a multiplicity of functional links and relations" 28 (ibid.) that are subject to this structure. While in this sense, space was already considered to be a product of relational systems instead of a quasi natural result of terrestrial conditions, at that time one still attempted to understand and explain the matter in terms of the methodological system of spatial science, in particular through identifying causalities and laws that one sought to clarify analytically chiefly with quantitative empirics and modelling. It was not until the 1990 s and 2000 s that broader approaches gained currency in the relational research paradigm, for instance those that have emphasized the constitution and organization of stakeholder agency or the role of institutions of various kinds (see e.g. Bathelt/Glückler 2012).

In the course of a further diversification of notions of space in the context of the cultural-theoretical turn, space is thirdly emphasized as having significance when considering in particular attributions and ascriptions of meaning in the conflict with the physical-material world. Basically this is about redefining the relationship between space and society. This is done ontologically through a strict separation of physical-material, socio-cultural and mental space, and epistemologically via a reversal of the relationship of space and society. Space is understood in the sense of Werlen's concept of social geography as a manifestation of societal structures (regulative systems, communication, policies) as well as individual experiences, positings and practices that 'produce' space (see below for this central concept in Lefebvre).

27 | Personal translation of: "[...] Form der Ordnung des Nebeneinanders der Dinge über unterschiedliche Distanzen hinweg."

28 | Personal translation of: "[...] Konstellation von Gegebenheiten verstanden, die sich durch eine bestimmte Anordnungsstruktur und eine Vielzahl funktionaler Verknüpfungen bzw. Relationen auszeichnen."

E-Book von Christian Wille, christian.wille@uni.lu 27.01.2016 17:18

Copyright 2016, transcript Verlag, Bielefeld 
"There is an urgent need to systematically take into account the fundamental principles of Modernity, on which postmodern societies are based in many ways, not only in a sociocultural sense, but - moving on - also in relation to a corresponding geographical view of the world. That means that a space preceding every action can no longer be in the centre of our view of the world, but rather the acting, physical subjects, who from their terrestrialspatial position [...] realize an appropriation of the world around them" ${ }^{29}$ (Werlen 2009: 153).

This aims at leaving behind the traditionally strong position of space in the sense of the above-mentioned container space in favour of the analysis of societal spatial relationships. Space is here also differentiated in a metaphorical sense, when material aspects are largely ignored and structures of order or relationships are subsumed under one umbrella term.

\subsubsection{Approaches to Spatial Constructions in this Volume}

The totality of the approaches mentioned here enables us to observe social phenomena with their physical-material aspects as a relational network, as well as the meanings embedded or mobilized in the processes that produce such spatial relations. These two specific perspectives on space, one relational-descriptive and the other symbolic-interpretative, are often discussed together in space-sensitive studies and, in the context of the border, are usually considered against the foil of a territorial nation-state order. This foil is then frequently employed to serve as an 'underlay' for the social, forming a mosaic of container spaces, which however need to be regarded in relational and symbolic terms.

The presented approaches and their nexuses, which in many studies are only implied and not explicitly detailed, encourage a blurred use of the category of 'space'. At the same time, however, they offer multiple points of reference across disciplines that have been instrumental in assuring the popularity of the spatial turn and that are also applied fruitfully for this volume. In the context of the border, the concepts of space concerned with relations and significations have proven to be particularly productive. They help in overcoming the notion of the impact and influence of (national) container spaces - from which scientific thought is often unable to detach itself - and examining the dissolution, particularly visible in cross-border contexts, of the seemingly 'national' unity of territorial space and

29 | Personal translation of: "Es ist dringend erforderlich, den Grundprinzipien der Moderne, auf denen spätmoderne Gesellschaften in vielerlei Hinsicht aufbauen, nicht nur in sozial-kultureller Beziehung, sondern - weiterführend - auch bezogen auf ein entsprechendes geographisches Weltbild konsequent Rechnung zu tragen. Das heißt, dass nicht mehr ein jedem Handeln vorausgehender Raum im Zentrum des Weltbildes stehen kann, sondern die handelnden, körperlichen Subjekte, die von ihrer erdräumlichen Position aus [...] 'WeltBindungen' [...] verwirklichen."

E-Book von Christian Wille, christian.wille@uni.lu 27.01.2016 17:18

Copyright 2016, transcript Verlag, Bielefeld 
the social space inscribed in it. The various concepts of space therefore help to analytically decode and empirically examine the 'nesting' of spatial types assumed here and the processes of their 'denesting' yet to be investigated. So this volume is not concerned with displacing the diversity of spatial notions in favour of one model but instead with productively exploiting their plurality and the approaches linked to them. Accordingly the case studies attempt to "take into account the single case and in doing so make use of the theoretical diversity of conceiving space" $^{30}$ (Kajetzke/Schroer 2010: 203).

This approach to space using multiple perspectives is not new but was and continues to be practised by a number of scholars. One of these is the abovementioned French social philosopher Henri Lefebvre. He sees space as socially produced and links the process of its production to questions of social theory (see Lefebvre 1991 [1974]); he distinguishes between three spatial formants: (1) the spatial practice (pratique spatiale) that produces a materially perceived space (l'espace perçu) in the course of everyday action; (2) the representation of space (représentation de l'espace) in the course of influential practices that create a space of knowledge, signs and codes (l'espace conçu) and (3) the space of representation (espace de représentation) of the experiencing subjects who produce a lived space (l'espace vécu) in a symbolic sense. While it is not possible to dwell on Lefebvre's work here, we can note that his concern is to conceive physical and social space together in favour of a practice-oriented perspective, to decode the empirical interaction of different spatial concepts, to emphasize the role of the (human) body for space constructions and to adopt a perspective on space that is directed towards contingency or process (see Kajetzke/Schroer 2010: 196).

Michel de Certeau pursues the same idea when he introduces the distinction between place (lieu) as the 'objective' physical-material world and space (espace) as a materiality 'coated' with meaning (see de Certeau 1984 [1980]). The French historian and philosopher focuses on so-called practices of place (pratiques de lieu) which designate the way we deal with and conduct ourselves in places and which ultimately result in the production of space. Practices of place then stand for how individuals appropriate the physical-material world and confer meaning on it. The much-quoted passage that a road only turns into a space by someone walking along it (see de Certeau 1984 [1980]) should however not obscure the fact that places also 'transform' into spaces via narrations and via the ascriptions of meaning connected to them. De Certeau is thus also building a praxeological bridge between physical and social space; but he conceives space explicitly as a social production embedded in time and movement that can be reproduced as a topological structure and connected back to the relational concept of space.

The approach of "media spaces of identity" (Hipfl 2004: 16ff.) follows epistemologically Lefebvre and de Certeau, but for Brigitte Hipfl codes and

30 | Personal translation of: "[...] den Einzelfall [zu] berücksichtigen und sich dabei der theoretischen Vielfalt, Raum zu denken, [zu] bedienen."

E-Book von Christian Wille, christian.wille@uni.lu 27.01.2016 17:18

Copyright 2016, transcript Verlag, Bielefeld 
representations as well as the metaphorical concept of space play a prominent role. The media and cultural studies scholar assumes that "media, identity and space are inseparably connected and constitute each other"31 (Hipfl 2004: 16). Against this backdrop, she distinguishes (1) the production of geopolitical spaces that are produced via news coverages or the attributions of meaning and differentiations embedded in them. She is thus concerned with 'imaginative geographies' (see Said 1978) which construct identities and can be linked to the notion of 'imagined communities' (see Anderson 1983). In addition, Hipfl understands media themselves as spaces, namely as (2) semiotic spaces which display formations of identity apparent in differentiations, border crossings, inclusions and exclusions produced in them. Finally Hipfl (2004) opens up an analytical approach that centres on the reception of media. The concept of (3) the in-between spaces that are created in the interaction between media and recipients aims to direct the focus to the identity choices (of the semiotic spaces) conveyed by media. At the same time, it seeks to draw attention particularly to their reinterpretation or their contingent appropriations which are not rooted in the media themselves but in the relationship between media and recipients. Even though Hipfl (2004) develops a different trialectics of spatial types to Lefebvre, she succeeds in using the plurality of the notion of space to find an overarching grasp on social productions of space and identities and make them analytically accessible.

These examples of conceiving 'space' in multiple ways and making productive use of this circumstance assume the social dependency and processuality of spaces. In investigating them it is not the spaces 'as such' that are examined but the practices of their production with the involved subjects, bodies, artefacts, world views, meanings and power relations. This "methodological investigative setting"32 (Bachmann-Medick 2006: 303) - based on and following social practices and their materializations - can be applied to various forms of spatial constructions, which however frequently overlap empirically. Linguistic-communicative spatial constructions (e.g. imaginative geographies, semiotic spaces, l'espace conçu) are more accessible via approaches of discourse theory and semiotics for revealing space-related semantizations and their performative techniques of attribution and representation. Spatial constructions of everyday practices (e.g. l'espace vécu, les espaces/pratiques de lieu) can be more easily reassembled via practicerelated approaches that address the subjects' everyday geographies as topological structures and symbolic spatializations. Crucial for both forms of spatial production are relations and topologies as well as attributions and interpretations of meaning related to the physical-material world, which in turn permit statements about identity constructions. For while differentiations, relations, 'talking' of an

31 | Personal translation of: “[...] Medien, Identität und Raum untrennbar miteinander verknüpft sind und sich gegenseitig konstituieren."

32 | Personal translation of: "Methodische Untersuchungseinstellung."

E-Book von Christian Wille, christian.wille@uni.lu 27.01.2016 17:18

Copyright 2016, transcript Verlag, Bielefeld 
interior/exterior indicate (space-related) differentiations, these at the same time inform about (self-)positionings and thus about identities.

Based on the above, the level of meaning and the contingency of spaces and/ or identities constitute a guiding theme in this volume. We differentiate between three perspectives of investigation which, drawing on different concepts of space, are developed in the following chapters, but also overlap. These are (1) a power-critical perspective on space that addresses in particular policies and normalizations that take effect and are negotiated in spatial construction; (2) a media-oriented perspective on space which sees these as constructors and projection surfaces, with media themselves being identified as spaces and (3) a subject-centered perspective that examines spatial constructions in the course of everyday practices. These perspectives focus partly on different matters, but consistently on the construction processes of spaces while avoiding thinking in preset spatial categories.

The power-critical perspective on spatial constructions pervades this volume as a whole, in particular chapter 3. Point of departure here is the assumption that spaces are more or less manifestly shaped by power relationships, more precisely by policies and normalizations. These are revealed by examining differentiations, attributions of meaning, hierarchizations and other techniques of the exercise of power that are inherent in spatial constructions. Here we will also draw on observations by Julia Lossau (2004) and Michel Foucault (1977) among others.

In her studies of the early 2000 s, which are more along the lines of linguisticcommunicative spatial constructions, Lossau (2004) examines in how far the social is naturalized through practices of location or via symbolic spatializations. Her observations, drawing on Said (1978), are based on a constructivist understanding of space, i.e. that reality is always "created via continuous attributions of meaning; via speaking or writing" and that the representations used for this "are always also embedded in questions about power and domination"33 (Lossau 2003: 104). 'Doing representation' - as a performative practice of spatial construction - is thus always linked to a "policy of localization" ${ }^{34}$ (Lossau 2002). Adopting a powercritical perspective then means enquiring who represents or "localizes" what and how and to what purpose. The analytical work is thus less concerned with the objects used in spatial constructions, but rather with "which way these objects are perceived and thus (re)produced"35 (Lossau 2003: 110).

Another but similar perspective was developed by Foucault who focuses more on spatial constructions of everyday practice. These primarily refer

33 | Personal translation of: “[...] erst [entsteht] durch kontinuierliche Bedeutungszuweisungen; durch Sprechen oder Schreiben [...]" [und dass die dafür verwendeten Repräsentationen] "[...] immer auch in Fragen nach Macht und Herrschaft eingelassen sind."

34 | Personal translation of: "Politik der Verortung."

35 | Personal translation of: "[...] auf welche Art und Weise diese Gegenstände [...] betrachtet und damit (re-)produziert werden." 
to architectures as media of control that produce, via their dispositions and materialities, steering effects, i.e. technologies of power with which bodies and cultural practices can be arranged and controlled (see Foucault 1977). Consequently one can inquire about the territorialization strategies of architecture or - as is partly done in chapter 3 - in an even more fundamental way, "which functions spatial productions fulfill in controlling a population and how human action and social participation can be controlled through territorialization and zoning"36 (Schreiber 2009: 202). In addition, Foucault enables a power-critical perspective where everyday practices are seen as focal points of spatial constructions. It is only in a second step that the analytical attention then directs itself to the spatial figures produced in each case; the primary focus is on the subjectifications and subjectivations ${ }^{37}$ which more or less 'guide' the spatial practices. These can be examined on the level of the subject by looking at logics of everyday culture that manifest themselves in social practices and the spatial relationships produced in them (see chapter 5). From the perspective of subjectifications, space-related representations can be examined for symbolic charging and coding - similar to the concept of the "policy of localization"38 (Lossau 2002) (see chapters 3 and 4). With his concept of governmentality, Foucault provides an effective tool for examining spatial constructions from a power-critical perspective and via a variety of approaches.

The media-oriented perspective on spatial constructions in this volume for the most part follows the research conducted in the context of the topographical turn (see Wagner 2010; Weigel 2002). This refers both to the examination of spatially constitutive codings and technologies of representation in cultural media and the semiotic reading of physical-material spaces. Space-creating construction mechanisms play a key role in such 'topographical readings'. They are at the centre of the above-mentioned concept of 'imaginative geographies' developed by literary studies scholar Edward W. Said (see Said 1978). In his work he reconstructs among other things the orientalist discourse of the West and shows how the Other constructed there is instrumentalized for the colonial expansion of the West, or in other words "how imagined geographies were able to turn into powerful instruments for exercising power and also transforming the physical-material

36 | Personal translation of: "[...] welche Funktionen Raumproduktionen bei der Steuerung von Bevölkerung erfüllen und wie sich durch Territorialisieren und Zonieren menschliches Handeln und gesellschaftliche Teilhabe lenken lässt."

37 | We differentiate between processes of subjectification (see Althusser 1971) and subjectivation (see Bührmann/Schneider 2008: 176), the former meaning top-down, mostly institutional attributions and the latter bottom-up, generally individual appropriations within the general, neverending practices of identity-building.

38 | Personal translation of: "Politik der Verortung."

E-Book von Christian wille, christian.wille@uni.lu 27.01.2016 17:18

Copyright 2016, transcript Verlag, Bielefeld 
space"39 (Döring 2010: 96). Besides the power-critical aspects this is primarily about the performative dimension of the practices of the media discourse, more precisely about symbolic processes of attributions and representations of meaning through which spatial relationships and identities are established. Birgit Neumann's (2009: 118) reading of Said emphasizes this clearly: “Thus the acts of establishing borders have the function of increasingly homogenizing heterogenous spaces and creating spaces that are structured in a binary way and that can be put into the service of the self-affirmative separation of the own and the other." 40

The social geographers Annegret Harendt and Dana Sprunk (2011) also examine spatializing practices under performative aspects, specifically in the context of media coverages. They have developed, drawing on notions of literary studies, the concepts of 'narrated space' (erzählter Raum) and 'narrative space' (Erzählraum), attempting to emphasize two dimensions of imaginative geography that are analytically separable but interlock in their effect. In the 'narrated space' they focus on what is said and thus on space-related codings; the 'narrative space' by contrast centres on what is shown and thus the 'stage' and materiality of the staging of space. The latter opens up an additional aspect of media-related productions of space, since it complements the enquiry into the symbolic orders with that into the mise en scène of spatial stagings.

In this volume, cultural media are themselves also regarded as spaces. For this we use, among others, the notion of the interstice ${ }^{41}$, which is employed both for denoting physical-material arrangements and symbolic-metaphorical ones. While it places less emphasis on the aspect of power asymmetries, it does draw on post-colonial thought, when, in chapter 4 , interstices form the counterfoil to binary logics and the dissolution of boundaries becomes constitutive. Interstices then denote zones where borders are crossed and questioned, where a productivecreative negotiation of differences takes place and the own coexists beside the other or the private beside the public.

The subject-centered perspective on space in this volume addresses everyday practices and the spatial productions generated in them. As mentioned above, these can be reconstructed via practice- and/or action-theoretical approaches. The point of reference here is the approach of "everyday regionalizations"

39 | Personal translation of: “[...] wie aus imaginierten Geographien machtvolle Instrumente zur Herrschaftsausübung und zur Umgestaltung auch des physisch-materiellen Raums werden konnten."

40 | Personal translation of: "So haben die Akte der Grenzziehung die Funktion, heterogene Räume zunehmend zu vereinheitlichen und binär strukturierte Räume zu schaffen, die in den Dienst der selbstaffirmativen Separation des Eigenen und Fremden gestellt werden können."

41 | This only partly overlaps with Hipfl's (2004) concept of the in-between mentioned above.

42 | Personal translation of: "[...] alltäglichen Regionalisierungen.”

E-Book von Christian wille, christian.wille@uni.lu 
1997a), which focuses "on the human practice with particular consideration for the material means of action, their social interpretation and meaning"43 (Werlen 2007a: 66). Werlen thus takes the practices of the subjects as a point of departure for examining staged geographies in everyday life. On an analytical level, this involves constellations of objects and/or structures of relationships between artefacts and bodies that are created by subjects in social practices (relationalizations). A further aspect are attributions and signifcations that flow into social practices, condense into representations and in turn take effect on a social level. Both aspects - the observable and relationalizing action as well as the processes of meaning - refer to the physical-material world. Space is then regarded as a conceptional medium that in a relational-descriptive regard expresses "the different relationalizations of bodily subjects with other physical-material circumstances"44 (Werlen 1997b: 10). In a symbolic-interpretative respect it represents the subjects' attributions and significations produced in the course of relationalizations.

This approach is fundamentally suited for the investigation of spatial constructions in the context of the border since it overcomes the idea of powerful container spaces in favour of a relational and meaning-oriented perspective on space. However, the concept of action that this approach is based on limits the analysis of spatial practices in cross-border contexts. Werlen (2008:282) sees 'doing

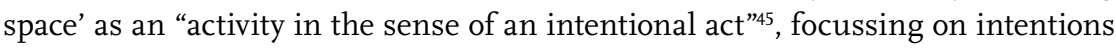
and purposes that subjects attune their actions to. This process is guided "more or less consciously by an intersubjective context of meaning" in the sense of a "socially and culturally prepared orientational grid" that "exists independently from the individual actor"46 (Werlen 2008: 287). This understanding of everyday practices follows an orientation along the lines of purpose and rules, thereby linking up with classical approaches of explaining agency, which, in the context of the border, only have limited efficacy. This is because they operate firstly with rational orientations of action (homo oeconomicus), with a normative-collective consensus on (il)legitimate action (homo sociologicus) as well as with intersubjectively and stably conceived orders of knowledge (homo significans); secondly they disregard the observable bodily agency and its materializations (see Reckwitz 2003). However, the analysis of everyday practices in this volume, particularly chapter 5, calls for spatial-theoretical links (via bodies, artefacts and their relationalizations),

43 | Personal translation of: “[...] auf die menschliche Praxis unter besonderer Berücksichtigung der räumlichen Bedingungen der materiellen Medien des Handelns, ihrer soziaIen Interpretation und Bedeutung."

44 | Personal translation of: "[...] die unterschiedlichen Relationierungen der körperlichen Subjekte mit anderen physisch-materiellen Gegebenheiten [...] zum Ausdruck [bringt]."

45 | Personal translation of: "[...] Tätigkeit im Sinne eines intentionalen Aktes.”

46 | Personal translation of: "[...] mehr oder weniger bewusst an einem intersubjektiven [...] Bedeutungszusammenhang" [im Sinne eines] "gesellschaftlich und kulturell vorbereitete[n] Orientierungsraster[s]", [das] "unabhängig vom einzelnen Handelnden besteht."

E-Book von Christian Wille, christian.wille@uni.lu 27.01.2016 17:18

Copyright 2016, transcript Verlag, Bielefeld 
and furthermore, in cross-border contexts there is usually less reason to impute rational assessment and expectancy of attaining a desired goal, an intersubjectivity as a 'social lubricant' or a 'proper' execution of (wherever) valid systems of rules and symbols. Rather, in the context of the border, everyday practices are marked by discontinuities, interpretative uncertainties and ambivalences (see Boeckler 2012: 48 ) that should be identified with a suitable concept of practices - as a focal point of spaces.

Here it is the praxeologically oriented approaches (e.g. Pierre Bourdieu, Anthony Giddens, Theodore Schatzki, Bruno Latour, Andreas Reckwitz) which with their own specific emphases - develop a perspective on human activities that takes cultural contingency and physical involvement with the physical-material world in equal measure into account. They understand social practices as physical representations and acts of comprehension that are held together by implicit knowledge and interlink with artefacts and natural things (see Moebius 2008: 59 and 61). Furthermore, the knowledge referred to here, i.e. the interpretations and attributions of meaning, has neither a supersubjective existence nor is it 'embedded' in the consciousness of the homo in praxi. Rather, it is part of the practical performance within which it is produced and forms the frame for "how concrete things should be interpreted in a practice and be dealt with practically"47 (Reckwitz 2010: 193). Therefore praxeological approaches are less concerned with the normative attunement of actions, or with the intersubjectivity of cultural codes, but primarily with the physical execution of practices that conceptionally include artefacts and in which attributions and interpretations of meaning are (re)produced in not necessarily predictable ways (see section 5.1). Blending the praxeological perspective on human activity with the concept of "everyday regionalizations" 48 (Werlen 1997a) provides suitable approaches to the subject-centered investigation of spatial constructions in the context of the border (see Wille 2014). This is because contingent interpretations and attributions of meaning become visible as a symbolic-interpretative dimension of spaces through the observation of practices while they occur, just as bodies and artefacts that participate in social practices make the relational-descriptive dimension of spaces empiricially manageable.

In this volume, the perspectives on spatial constructions presented here and the possible approaches for investigating them are adjusted according to the specific subject matters, further developed and empirically connected. We have thus in a way 'materialized' the plurality of the concept of space discussed above, while at the same time linking it to the 'neighbouring' fields of identities and borders in the individual case studies. Point of departure here is always the social element of 'doing' which is translated into institutional, media-related and everyday practices and examined in a power-critical and performative dimension.

47 | Personal translation of: “[...] wie konkrete Dinge in einer Praktik zu interpretieren und [...] praktisch zu handhaben sind."

48 | Personal translation of: "[...] alltäglichen Regionalisierungen."

E-Book von Christian Wille, christian.wille@uni.lu 27.01.2016 17:18

Copyright 2016, transcript Verlag, Bielefeld 


\subsection{References}

Abels, Heinz (2006): Identität. Über die Entstehung des Gedankens, dass der Mensch ein Individuum ist, den nicht leicht zu verwirklichenden Anspruch auf Individualität und die Tatsache, dass Identität in Zeiten der Individualisierung von der Hand in den Mund lebt, Wiesbaden: Verlag für Sozialwissenschaften.

Albert, Mathias/Brock, Lothar (1996): "Debordering the World of States. New Spaces in International Relations", in: New Political Science 18/1, 69-106.

Allmendinger, Phil/Haughton, Graham (2009): "Soft Spaces, Fuzzy Boundaries, and Metagovernance: The New Spatial Planning in the Thames Gateway", in: Environment and Planning A 41, 617-633.

Althusser, Louis (1971 [1970]): “Ideology and Ideological State Apparatuses" (trans. Ben Brewster), in: L. Althusser (ed.), Lenin and Philosophy and other Essays, New York: Monthly Review Press, 121-176.

Anderson, Benedict (2006): Imagined Communities: Reflections on the Origin and Spread of Nationalism, London/New York: Verso.

Audehm, Kathrin/Velten, Hans Rudolf (2007): “Einleitung”, in: Kathrin Audehm/ Hans Rudolf Velten (eds.), Transgression - Hybridisierung - Differenzierung. Zur Performativität von Grenzen in Sprache, Kultur und Gesellschaft (= Scenae, vol. 4), Freiburg i. Br./Berlin/Wien: Rombach, 9-40.

Avanza, Martina/Laferté, Gilles (2005): "Dépasser la 'construction des identités'? Identification, image sociale, appartenance”, in: Genèses 61, 134-152.

Bachmann-Medick, Doris (2006): Cultural Turns. Neuorientierungen in den Kulturwissenschaften, Reinbek bei Hamburg: Rowohlt.

Bathelt, Harald/Glückler, Johannes (2012): Wirtschaftsgeographie: ökonomische Beziehungen in räumlicher Perspektive, Stuttgart: UTB.

Beck, Ulrich/Giddens, Anthony/Lash, Scott (1994): Reflexive Modernization: Politics, Tradition and Aesthetics in the Modern Social Order, Stanford: Stanford University Press.

Beck, Ulrich/Beck-Gernsheim, Elisabeth (2001): Individualization: Institutionalized Individualism and its Social and Political Consequences, London/Thousand Oaks: Sage.

Beetham, Gwendolyn/Fernández, Melissa (2010): "Inter/Trans/Post-Disciplinarity: Explorations of Encounters across Disciplines", in: Graduate Journal of Social Science 7, 7-13.

Benjamin, Walter (1999): The Arcades Project, prepared on the basis of the German volume ed. by Rolf Tiedemann (trans. Howard Eiland and Kevin McLaughlin), Cambridge MA: The Belknap Press of Harvard University Press.

Boeckler, Marc (2012): "Borderlands", in: Nadine Marquardt/Verena Schreiber (eds.), Ortsregister. Ein Glossar zu Räumen der Gegenwart, Bielefeld: transcript, 44-49. 
Böckler, Stefan (2007): “Grenze und frontier: Zur Begriffs- und Sozialgeschichte zweier Schließungsparadigmen der Moderne”, in: Petra Deger/Robert Hettlage (eds.), Der europäische Raum. Die Konstruktion europäischer Grenzen, Wiesbaden: Verlag für Sozialwissenschaften, 25-48.

Bourdieu, Pierre (1972): Esquisse d'une théorie de la pratique. Précédé de trois études d'ethnologie kabyle, Paris: Seuil.

Bourdieu Pierre, (1980): Le sens pratique, Paris, Minuit.

Bröckling, Ulrich/Krasmann, Susanne/Lemke, Thomas (2000): “Gouvernementalität, Neoliberalismus und Selbst-technologien. Eine Einleitung”, in: Ulrich Bröckling/Susanne Krasmann/Thomas Lemke (eds.), Gouvernementalität der Gegenwart. Studien zur Ökonomisierung des Sozialen, Frankfurt a. M.: Suhrkamp, 7-40.

Brubaker, Rogers (2001): “Au-delà de l'identité", in: Actes de la recherche en sciences sociales 139, 66-85.

Bühler, Benjamin (2012): “Grenze. Zur Wort- und Theoriegeschichte”, in: Trajekte 24, 31-34.

Bührmann, Andrea/Schneider, Werner (2008): Vom Diskurs zum Dispositiv.

Eine Einführung in die Dispositivanalyse, Bielefeld: transcript.

Butler, Judith (2006 [1990]): Gender Trouble, London/New York: Routledge.

Butler, Judith (2008a [1990]): “Bodily Inscriptions, Performative Subversions”, in:

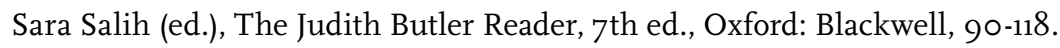

Butler, Judith (2008b [1990]): “Imitation and Gender Insubordination", in: Sara

Salih (ed.), The Judith Butler Reader, 7th ed., Oxford: Blackwell, 119-137.

Chaffee, Daniel (2011): “Reflexive Identities”, in: Anthony Elliott (ed.), Routledge

Handbook of Identity Studies, London/New York: Routledge, 100-111.

de Certeau, Michel (1984 [French original 1980]): The Practice of Everyday Life

(trans. Steven Rendall), Berkeley/Los Angeles: University of California Press.

Derrida, Jacques (1982a [French original 1978]): The Truth in Painting (trans.

Geoff Bennington and Ian McLeod), Chicago: University of Chicago Press.

Derrida, Jacques (1982b [French original 1978]): "Différance” (trans. Alan Bass),

in: Margins of Philosophy, Chicago: University of Chicago Press, 3-27.

Després, Carole/Lawrence, Roderick J. (2004): “Introduction”, in: Futures 36, 397405.

Döring, Jörg (2010): “Spatial Turn”, in: Stephan Günzel (ed.), Raum. Ein interdisziplinäres Handbuch, Stuttgart: Metzler, 90-99.

Eigmüller, Monika (2006): “Der duale Charakter der Grenze. Bedingungen einer aktuellen Grenztheorie”, in: Monika Eigmüller/Georg Vobruba (eds.), Grenzsoziologie. Die politische Strukturierung des Raums, Wiesbaden: Verlag für Sozialwissenschaften, 55-73.

Elias, Norbert (1986): “Figuration”, in: Bernhard Schäfers (ed.), Grundbegriffe der Soziologie, Opladen: Leske + Budrich, 88-91.

Elliott, Anthony (ed.) (2011): Routledge Handbook of Identity Studies, London/ New York: Routledge. 
Emirbayer, Mustafa (1997): “Manifesto for a Relational Sociology”, in: American Journal of Sociology 103/2, 281-317.

Faber, Richard/Naumann, Barbara (eds.) (1995): Literatur der Grenze - Theorie der Grenze, Würzburg: Königshausen \& Neumann.

Fischer-Lichte, Erika (2005): “Grenze oder Schwelle? Zum Verhältnis von Kunst und Leben”, in: Sprache und Literatur 36, 3-14.

Flusser, Vilém (1996): Zwiegespräche. Interviews 1967-1991, Göttingen: European Photography.

Flusser, Vilém (2009): Kommunikologie weiter denken. Die Bochumer Vorlesungen, Frankfurt a.M.: Fischer.

Foucault, Michel (1977 [French original 1975]): Discipline and Punish: The Birth of the Prison (trans. Alan Sheridan), New York: Pantheon Books.

Foucault, Michel (1982): “The Subject and Power“, in: Hubert Dreyfus/Paul Rabinow, Michel Foucault. Beyond Structuralism and Hermeneutics (trans. Robert Hurley et. al), Chicago: The University of Chicago Press, 208-226.

Foucault, Michel (1993): "About the Beginning of the Hermeneutics of the Self" (orig. in English, ed. by Thomas Keenan and Mark Blasius), in: Political Theory, vol. 21/2,198-227.

Foucault, Michel (1998 [French original 1963]) "A preface to transgression" (trans. Donald F. Bouchard and Sherry Simon, slightly modified), in: James D. Faubion (ed.), Aesthetics, method and epistemology, New York: New Press, 69-87.

Foucault, Michel (2007 [French original 2004]): Security, Territory, Population. Lectures at the Collège de France, 1977-1978 (trans. Graham Burchell), New York: Picador.

Füller, Henning/Marquardt, Nadine, (2009): "Gouvernementalität in der humangeographischen Diskursforschung”, in: Georg Glaszke/Annika Mattissek (eds.), Handbuch Diskurs und Raum. Theorien und Methoden für die Humangeographie sowie die sozial- und kulturwissenschaftliche Raumforschung, Bielefeld: transcript, 83-106.

Gertenbach, Lars (2012): "Governmentality Studies. Die Regierung der Gesellschaft im Spannungsfeld von Ökonomie, Staat und Subjekt”, in: Stephan Moebius (ed.), Kultur. Von den Cultural Studies bis zu den Visual Studies. Eine Einführung, Bielefeld: transcript, 109-127.

Giddens, Anthony (1991): Modernity and Self-Identity: Self and Society in the Late Modern Age, Cambridge: Polity Press.

Goffman, Erving (1974): Frame Analysis. An Essay on the Organization of Experience, Boston: Northeastern University Press.

Goffman, Erving (1959): The Presentation of Self in Everyday Life, New York: Anchor Books.

Graumann, Carl Friedrich (1983): “On Multiple Identities”, in: International Social Science Journal 35, 309-321.

Greverus, Ina-Maria (1995): Die Anderen und Ich, Darmstadt: Wissenschaftliche Buchgesellschaft. 
Guldin, Rainer (2011): “Ineinander greifende graue Zonen. Vilém Flussers Bestimmung der Grenze als Ort der Begegnung”, in: Christoph Kleinschmidt/ Christine Hewel (eds.), Topographien der Grenze. Verortungen einer kulturellen, politischen und ästhetischen Kategorie, Würzburg: Königshausen \& Neumann, 39-48.

Halpern, Catherine (2009): Identité(s). L'individu, le groupe, la société, Paris: Editions Sciences Humaines.

Han, Sam (2011): “The Fragmentation of Identity Theories”, in: Anthony Elliott (ed.), Routledge Handbook of Identity Studies, London/New York: Routledge, 83-99.

Harendt, Annegret/Sprunk, Dana (2011): “Erzählter Raum und Erzählraum: (Kultur-)Raumkonstruktion zwischen Diskurs und Performanz”, in: Social Geography $6,15-27$.

Hark, Sabine (2005): “Inter/Disziplinarität. Gender Studies Revisited”, in: Heike Kahlert/ Barbara Thiessen/Ines Weller (eds.), Quer denken - Strukturen verändern. Gender Studies zwischen Disziplinen, Wiesbaden: Verlag für Sozialwissenschaften, 61-89.

Heckhausen, Heinz (1987): “Interdisziplinäre Forschung zwischen Intra-, Multi- und Chimären-Disziplinarität”, in: Jürgen Kocka (ed.), Interdisziplinarität: Praxis - Herausforderung - Ideologie, Berlin: Suhrkamp, 129-145.

Hipfl, Brigitte (2004): “Mediale Identitätsräume. Skizzen zu einem 'spatial turn' in der Medien- und Kommunikationswissenschaft”, in: Brigitte Hipfl/Elisabeth Klaus/Uta Scheer (eds.), Identitätsräume. Nation, Körper und Geschlecht in den Medien. Eine Topografie, Bielefeld: transcript, 16-50.

van Houtum, Henk/van Naerssen, Ton (2002): "Bordering, Ordering and Othering”, in: Journal of Economic and Social Geography 93/2, 125-136.

IPSE (2010) (ed.): Doing Identity in Luxemburg. Subjektive Aneignungen - institutionelle Zuschreibungen - sozio-kulturelle Milieus, Bielefeld: transcript.

IPSE (2011a) (ed.): Doing Identity in Luxembourg. Subjective Appropriations - Institutional Attributions - Socio-Cultural Milieus, Bielefeld: transcript.

IPSE (2011b) (ed.): Construire des identités au Luxembourg. Appropriations subjectives - Projections institutionnelles - Milieux socio-culturels, Paris: Berg International.

Jungert, Michael (2010): “Was zwischen wem und warum eigentlich? Grundsätzliche Fragen der Interdisziplinarität”, in: Michael Jungert/Elsa Romfeld/Thomas Sukopp/Uwe Voigt (eds.), Interdisziplinarität. Theorie, Praxis, Probleme, Darmstadt: Wissenschaftliche Buchgesellschaft, 1-11.

Kajetzke, Laura/Schroer, Markus (2010): “Sozialer Raum: Verräumlichung”, in: Stephan Günzel (ed.), Raum. Ein interdisziplinäres Handbuch, Stuttgart: Metzler, 192-203.

Kalscheuer, Britta (2005): “Die raum-zeitliche Ordnung des Transdifferenten”, in: Lars Allolio-Näcke/Britta Kalscheuer/Arne Manzeschke (eds.), Differenzen 
anders denken. Bausteine zu einer Kulturtheorie der Transdifferenz, Frankfurt a.M.: Campus, 68-85.

Kaufmann, Stefan/Bröckling, Ulrich/Horn, Eva (2002): “Einleitung”, in: Stefan Kaufmann/Ulrich Bröckling/Eva Horn (eds.), Grenzverletzer. Von Schmugglern, Spionen und anderen subversiven Gestalten, Berlin: Kulturverlag Kadmos, 7-22.

Keupp, Heiner/Ahbe, Thomas/Gmür, Wolfgang/Höfer, Renate/Mitzscherlich, Beate/Kraus, Wolfgang/Straus, Florian (2006): Identitätskonstruktionen. Das Patchwork der Identitäten in der Spätmoderne, Reinbek bei Hamburg: Rowohlt.

Krappmann, Lothar (2005): Soziologische Dimensionen der Identität. Strukturelle Bedingungen für die Teilnahme an Interaktionsprozessen, Stuttgart: KlettCotta.

Lahire, Bernhard (1998): L'homme pluriel. Les ressorts de l'action, Paris: Nathan. Lamping, Dieter (2001): Über Grenzen - eine literarische Topographie, Göttingen: Vandenhoek \& Ruprecht.

Lask, Tomke (2002): "Wir waren doch immer Freunde in der Schule". Einführung in die Anthropologie der Grenzräume - Europäisches Grenzverständnis am Beispiel Leidingens, Saarbrücken: Röhrig.

Lefebvre, Henri (1991 [French Original 1974]): The Production of Space (trans. Donald Nicholson-Smith), Oxford: Blackwell.

Lemke, Thomas (2008): “Gouvernementalität”, in: Clemens Kammler (ed.), Foucault-Handbuch. Leben - Wirkung - Werk, Stuttgart/Weimar: Verlag J. B. Metzler, 260-263.

Löffler, Winfried (2010): "Vom Schlechten des Guten: Gibt es schlechte Interdisziplinarität?”, in: Michael Jungert/Elsa Romfeld/Thomas Sukopp/Uwe Voigt (eds.), Interdisziplinarität. Theorie, Praxis, Probleme, Darmstadt: Wissenschaftliche Buchgesellschaft, 157-172.

Lösch, Klaus (2005): "Begriff und Phänomen der Transdifferenz: Zur Infragestellung binärer Differenzkonstrukte”, in: Lars Allolio-Näcke/Britta Kalscheuer/ Arne Manzeschke (eds.), Differenzen anders denken. Bausteine zu einer Kulturtheorie der Transdifferenz, Frankfurt a.M.: Campus, 26-49.

Lossau, Julia (2002): Die Politik der Verortung. Eine postkoloniale Reise zu einer "ANDEREN" Geographie der Welt, Bielefeld: transcript.

Lossau, Julia (2003): "Geographische Repräsentationen: Skizze einer anderen Geographie”, in: Hans Gebhardt/Paul Reuber/Günther Wolkersdorfer (eds.), Kulturgeographie. Aktuelle Ansätze und Entwicklungen, Heidelberg/Berlin: Spektrum Akademischer Verlag, 101-111.

Maihofer, Andrea (2005): "Inter-, Trans- und Postdisziplinarität. Ein Plädoyer wider die Ernüchterung”, in: Heike Kahlert/Barbara Thiessen/Ines Weller (eds.), Quer denken - Strukturen verändern. Gender Studies zwischen Disziplinen, Wiesbaden: Verlag für Sozialwissenschaften, 185-202. 
Mayring, Philipp (2002): Einführung in die qualitative Sozialforschung, Weinheim: Beltz.

Medick, Hans (1995): "Grenzziehungen und die Herstellung des politisch-sozialen Raumes. Zur Begriffsgeschichte und politischen Sozialgeschichte der Grenzen und der frühen Neuzeit", in: Richard Faber/Barbara Naumann (eds.), Literatur der Grenze - Theorie der Grenze, Würzburg: Königshausen \& Neumann, 211-224.

Moebius, Stephan (2008): "Handlung und Praxis. Konturen einer poststrukturalistischen Praxistheorie”, in: Stephan Moebius/Andreas Reckwitz (eds.), Poststrukturalistische Sozialwissenschaften, Frankfurt a.M.: Suhrkamp, 58-74.

Neumann, Birgit (2009): "Imaginative Geographien in kolonialer und postkolonialer Literatur: Raumkonzepte der (Post-)Kolonialismusforschung”, in: Wolfgang Hallet/Birgit Neumann (eds.), Raum und Bewegung in der Literatur. Die Literaturwissenschaften und der Spatial Turn, Bielefeld: transcript, 115-138.

Newman, Davis (2001): "Boundaries, Borders, and Barriers: Changing Geographic Perspectives on Territorial Lines", in: Mathias Albert/David Jacobson/ Yosef Lapid (eds.), Identities, Borders, Orders. Rethinking International Relations Theory, Minnesota: University of Minnesota, 137-151.

Parr, Rolf (2008): "Liminale und andere Übergänge. Theoretische Modellierungen von Grenzzonen, Normalitätsspektren, Schwellen, Übergängen und Zwischenräumen in Literatur- und Kulturwissenschaft", in: Achim Geisenhanslüke/Georg Mein (eds.), Schriftkultur und Schwellenkunde, Bielefeld: transcript, $11-6_{3}$.

Reckwitz, Andreas (2001): "Der ldentitätsdiskurs zum Bedeutungswandel einer sozialwissenschaftlichen Semantik", in: Werner Rammert/Gunther Knauthe/ Klaus Buchenau/Florian Altenhoner (eds.), Kollektive Identitäten und Kulturelle Innovationen: ethnologische, soziologische und historische Studien, Leipzig: Leipziger Universitätsverlag, 21-38.

Reckwitz, Andreas (2003): "Grundelemente einer Theorie sozialer Praktiken: Eine sozialtheoretische Perspektive”, in: Zeitschrift für Soziologie 32/4, 282301.

Reckwitz, Andreas (2008): "Praktiken und Diskurse. Eine sozialtheoretische und methodologische Relation", in: Herbert Kalthoff/Stefan Hirschauer/Gesa Lindemann (eds.), Theoretische Empirie. Zur Relevanz qualitativer Sozialforschung, Frankfurt a.M.: Suhrkamp, 188-209.

Reckwitz, Andreas (2010): "Auf dem Weg zu einer kultursoziologischen Analytik zwischen Praxeologie und Poststrukturalismus", in: Monika Wohlrab-Sahr (ed.), Kultursoziologie. Paradigmen - Methoden - Fragestellungen, Wiesbaden: Verlag für Sozialwissenschaften, 179-205.

Reckinger, Rachel/Schulz, Christian/Wille, Christian (2011a): "Preface”, in: IPSE (ed.), Doing Identity in Luxembourg. Subjective Appropriations - Institutional Attributions - Socio-Cultural Milieus, Bielefeld: transcript, 7-9. 
Reckinger, Rachel/Schulz, Christian/Wille, Christian (2011b): “Identity Constructions in Luxembourg”, in: IPSE (ed.), Doing Identity in Luxembourg. Subjective Appropriations - Institutional Attributions - Socio-Cultural Milieus, Bielefeld: transcript, 291-294.

Reckinger, Rachel/ Wille, Christian (2011b): "Researching Identity Constructions”, in: IPSE (ed.), Doing Identity in Luxembourg. Subjective Appropriations - Institutional Attributions - Socio-Cultural Milieus, Bielefeld: transcript, 1134.

Renn, Joachim/Straub, Jürgen (2002): “Transitorische Identität. Der Prozesscharakter moderner personaler Selbstverhältnisse”, in: Joachim Renn/Jürgen Straub (eds.), Transitorische Identität. Der Prozesscharakter des modernen Selbst, Frankfurt a.M.: Campus, 10-31.

Ricoeur, Paul (1992 [French original 1990]): Oneself as Another (trans. Kathleen Blamey), Chicago: University of Chicago Press.

Roll, Christine/Pohle, Frank/Myrczek, Matthias (eds.) (2010): Grenzen und Grenzüberschreitungen. Bilanz und Perspektiven der Frühneuzeitforschung, Köln/Weimar/Wien: Böhlau.

Rosa, Hartmut (2007): “Identität”, in: Jürgen Straub/Arne Weidemann (eds.), Handbuch interkulturelle Kommunikation und Kompetenz. Grundbegriffe Theorien - Anwendungsfelder, Stuttgart: Metzler.

Ruano-Borbolan, Jean-Claude (1998): L'identité. L'individu, le groupe, la société, Auxerre: Sciences Humaines.

Said, Edward W. (1978): Orientalism, New York: Pantheon Books.

Schreiber, Verena (2009): “Raumangebote bei Foucault”, in: Georg Glasze/Annika Mattissek (eds.), Handbuch Diskurs und Raum. Theorien und Methoden für die Humangeographie sowie die sozial- und kulturwissenschaftliche Raumforschung, Bielefeld: transcript, 199-212.

Schroer, Markus (2008): “'Bringing Space Back In' - Zur Relevanz des Raums als soziologische Kategorie”, in: Jörg Döring/Tristan Thielmann (eds.), Spatial Turn. Das Raumparadigma in den Kultur- und Sozialwissenschaften, Bielefeld: transcript, 125-148.

Sennett, Richard (1996): "Etwas ist faul in der Stadt", in: Die Zeit, 26. Januar, 47-48.

Simmel, Georg (1992 [1903]): "Der Raum und die räumlichen Ordnungen der Gesellschaft”, in: Otthein Rammstedt (ed.), Georg Simmel: Soziologie. Untersuchungen über die Formen der Vergesellschaftung (= complete edition, vol. 11), Frankfurt a.M.: Suhrkamp, 687-790.

Soja, Edward W. (1989): Postmodern Geographies: The Reassertion of Space in Critical Social Theory, London: Verso.

Soja, Edward W. (1996): Thirdspace: Journeys to Los Angeles and Other Real-andImagined Places, Oxford: Blackwell. 
Somers, Margaret R./Gibson, Gloria D. (1994): "Reclaiming the Epistemological 'Other': Narrative and the Social Constitution of Identity”, in: Craig Calhoun (ed.), Social Theory and the Politics of Identity, Oxford: Blackwell, 37-99.

Straub, Jürgen (2004): “Identität”, in: Friedrich Jaeger/Burkhard Liebsch (eds.), Handbuch der Kulturwissenschaften. Grundlagen und Schlüsselbegriffe, Stuttgart: Metzler, 277-303.

Turner, Victor (1982): “Liminal to Liminoid, in Play, Flow, and Ritual: An Essay in Comparative Symbology”, in: Victor Turner, Ritual to Theatre: The Human Seriousness of Play, University of Michigan, Ann Arbor: Performing Arts Journal Publications.

van Gennep, Arnold (1960 [French original 1909]): Rites of Passage (trans. Monika B. Vizedom and Gabrielle L. Caffee), Chicago: University of Chicago Press. Wagner, Kirsten (2010): “Topographical Turn”, in: Stephan Günzel (ed.), Raum. Ein interdisziplinäres Handbuch, Stuttgart: Metzler, 100-109.

Walter-Wastl, Doris (ed.) (2011): The Ashgate Research Companion to Border Studies, Farnham: Ashgate.

Warde, Alan/Martens, Lydia/Olsen, Wendy (1999): “Consumption and the Problem of Variety. Cultural Omnivorousness, Social Distinction and Dining out”, in: Sociology 33/1, 105-127.

Warde, Alan (2005): "Consumption and Theories of Practice”, in: Journal of Consumer Culture 5/2, 131-153.

Watkin, Christopher (2009): Phenomenology or Deconstruction? The Question of Ontology in Maurice Merleau-Ponty, Paul Ricoeur, Jean-Luc Nancy, Edinburgh: Edinburgh University Press.

Weichhart, Peter (1990): Raumbezogene Identität. Bausteine zu einer Theorie räumlich-sozialer Kognition und Identifikation, Stuttgart: Franz Steiner Verlag.

Weigel, Sigrid (2002): “Zum ‘topographical turn'. Kartographie, Topographie und Raumkonzepte in den Kulturwissenschaften”, in: KulturPoetik 2/2, 151-165.

Werlen, Benno (1997a): Sozialgeographie alläglicher Regionalisierungen, vol. 2: Globalisierung, Region und Regionalisierung, Stuttgart: Franz Steiner Verlag.

Werlen, Benno (1997b): “Einleitung”, in: Benno Werlen (ed.), Sozialgeographie alltäglicher Regionalisierungen, vol. 3: Ausgangspunkte und Befunde empirischer Forschung, Stuttgart: Franz Steiner Verlag, 9-16.

Werlen, Benno (2008): Sozialgeographie. Eine Einführung, Bern: Haupt.

Werlen, Benno (2009): “Geographie/Sozialgeographie”, in: Stephan Günzel (ed.), Raumwissenschaften, Frankfurt a.M.: Suhrkamp, 142-158.

Werlen, Benno (2010): Gesellschaftliche Räumlichkeit 1. Orte der Geographie, Stuttgart: Franz Steiner Verlag.

Wetherell, Margaret/Mohanty, Chandra Talpade (eds.) (2010): The Sage Handbook of Identities, Los Angeles/London/New Delhi/Singapore/Washington DC: Sage. 
Wiesmann, Urs/Biber-Klemm, Susette/Grossenbacher-Mansuy, Walter/Hirsch Hadorn, Gertrude/Hoffmann-Riem, Holger/Joye, Dominique/Pohl, Christian/Zemp, Elisabeth (2008): “Transdisziplinäre Forschung weiterentwickeln: Eine Synthese mit 15 Empfehlungen”, in: Frédéric Darbellay/Theres Paulsen (eds.), Herausforderung Inter- und Transdisziplinarität. Konzepte, Methoden und innovative Umsetzung in Lehre und Forschung, Lausanne: Presses Polytechniques et Universitaires Romandes, 174-179.

Wille, Christian (2014): "Räume der Grenze. Eine praxistheoretische Perspektive in den kulturwissenschaftlichen Border Studies”, in: Friederike Elias/Albrecht Franz/Henning Murmann/Ulrich Weiser (eds.), Praxeologie. Beiträge zur interdisziplinären Reichweite praxistheoretischer Ansätze in den Geistesund Sozialwissenschaften (=Materiale Textkulturen, vol. 3), Berlin: De Gruyter, $53-72$. 
Christian Wille, Rachel Reckinger, Sonja Kmec, Markus Hesse (eds.)

\section{SPACES AND}

IDENTITIES IN

\section{BORDER REGIONS}

Politics - Media - Subjects

[transcript] Culture and Social Practice 
Christian Wille, Rachel Reckinger, Sonja Kmec, Markus Hesse (eds.) Spaces and Identities in Border Regions

Culture and Social Practice 
E-Book von Christian Wille, christian.wille@uni.lu

27.01.2016 17:18

Copyright 2016, transcript Verlag, Bielefeld 
Christian Wille, Rachel Reckinger, Sonja Kmec, Markus Hesse (eds.)

\section{Spaces and Identities in Border Regions}

Politics - Media - Subjects

\section{[transcript]}




\section{Bibliographic information published by the Deutsche Nationalbibliothek}

The Deutsche Nationalbibliothek lists this publication in the Deutsche Nationalbibliografie; detailed bibliographic data are available in the Internet at http://dnb.d-nb.de

\section{(๔) 2015 transcript Verlag, Bielefeld}

All rights reserved. No part of this book may be reprinted or reproduced or utilized in any form or by any electronic, mechanical, or other means, now known or hereafter invented, including photocopying and recording, or in any information storage or retrieval system, without permission in writing from the publisher.

Cover layout: Kordula Röckenhaus, Bielefeld

Cover illustration: misterQM / photocase.de

English translation: Matthias Müller, müller translations (in collaboration with Jigme Balasidis)

Typeset by Mark-Sebastian Schneider, Bielefeld

Printed in Germany

Print-ISBN 978-3-8376-2650-6

PDF-ISBN 978-3-8394-2650-0 